\title{
Supplemental Report: Technetium-99 On-Line Monitoring by Beta Counting for Hanford Supernate Waste Solutions
}

by

R. A. Sigg

Westinghouse Savannah River Company

Savannah River Site

Aiken, South Carolina 29808

F. M. Pennebaker

W. T. Boyce

C. S. Nuessle

W. A. Spencer

R. Hayden (Contact)

DOE Contract No. DE-AC09-96SR18500

This paper was prepared in connection with work done under the above contract number with the U.S. Department of Energy. By acceptance of this paper, the publisher and/or recipient acknowledges the U.S. Government's right to retain a nonexclusive, royalty-free license in and to any copyright covering this paper, along with the right to reproduce and to authorize others to reproduce all or part of the copyrighted paper. 


\section{DISCLAIMER}

This report was prepared as an account of work sponsored by an agency of the United States Government. Neither the United States Government nor any agency thereof, nor any of their employees, makes any warranty, express or implied, or assumes any legal liability or responisibility for the accuracy, completeness, or usefulness of any information, apparatus, product or process disclosed, or represents that its use would not infringe privately owned rights. Reference herein to any specific commercial product, process or service by trade name, trademark, manufacturer, or otherwise does not necessarily constitute or imply its endorsement, recommendation, or favoring by the United States Government or any agency thereof. The views and opinions of authors expressed herein do not necessarily state or reflect those of the United States Government or any agency thereof.

This report has been reproduced directly from the best available copy.

Available for sale to the public, in paper, from: U.S. Department of Commerce, National Technical Information Service, 5285 Port Royal Road, Springtield, VA 22161, phone: (800) 553-6847, fax: (703) 605-6900

email: orders@ntis.fedworld.gov

online ordering: http://www.ntis.gov/ordering.htm

Available electronically at http://www.doe.gov/bridge

Available for a processing fee to U.S. Department of Energy and its contractors, in paper, from:

U.S. Department of Energy, Office of Scientific and Technical Information, P.O. Box 62,

Oak Ridge, TN 37831-0062,

phone: (865)576-8401,

fax: (865)576-5728

email: reportsbadonis.osti.gov 


\section{DISCLAIMER}

Portions of this document may be illegible in electronic image products. Images are produced from the best available original document. 


\title{
Supplemental Report: Technetium-99 On-Line Monitoring by Beta Counting for Hanford Supernate Waste Solutions
}

\author{
R.A. Sigg, F.M. Pennebaker, W.T. Boyce, C.S. Nuessle and W.A. Spencer \\ Westinghouse Savannah River Company \\ Building 773-41A, Aiken, SC 29808
}

\section{DISCLAIMER NOTICE}

This report was prepared by Westinghouse Savannah River Company, Inc. (WSRC) on behalf of the U.S. Department of Energy (DOE), as an account of work sponsored by BNFL, Inc. Neither WSRC, DOE, the U.S. Government, or any person acting on their behalf makes any warranty, express or implied, or assumes any legal responsibility for the accuracy, completeness, or usefulness of any apparatus, product or process disclosed, or represents that its use would not infringe on privately owned rights. Reference herein to any commercial product, process, or service by trade name, trademark, manufacturer, or otherwise, does not necessarily constitute or imply its endorsement, recommendation, or favoring by WSRC, DOE, or the U.S. Government. The views and opinions of authors expressed herein do not necessarily state or reflect those of WSRC, DOE, or the U.S. Government.

Savannah River Technology Center Westinghouse Savannah River Company

Aiken, SC 29808 
BNF-003-98-0285

Rev. 0

August 7, 2000

Approvals
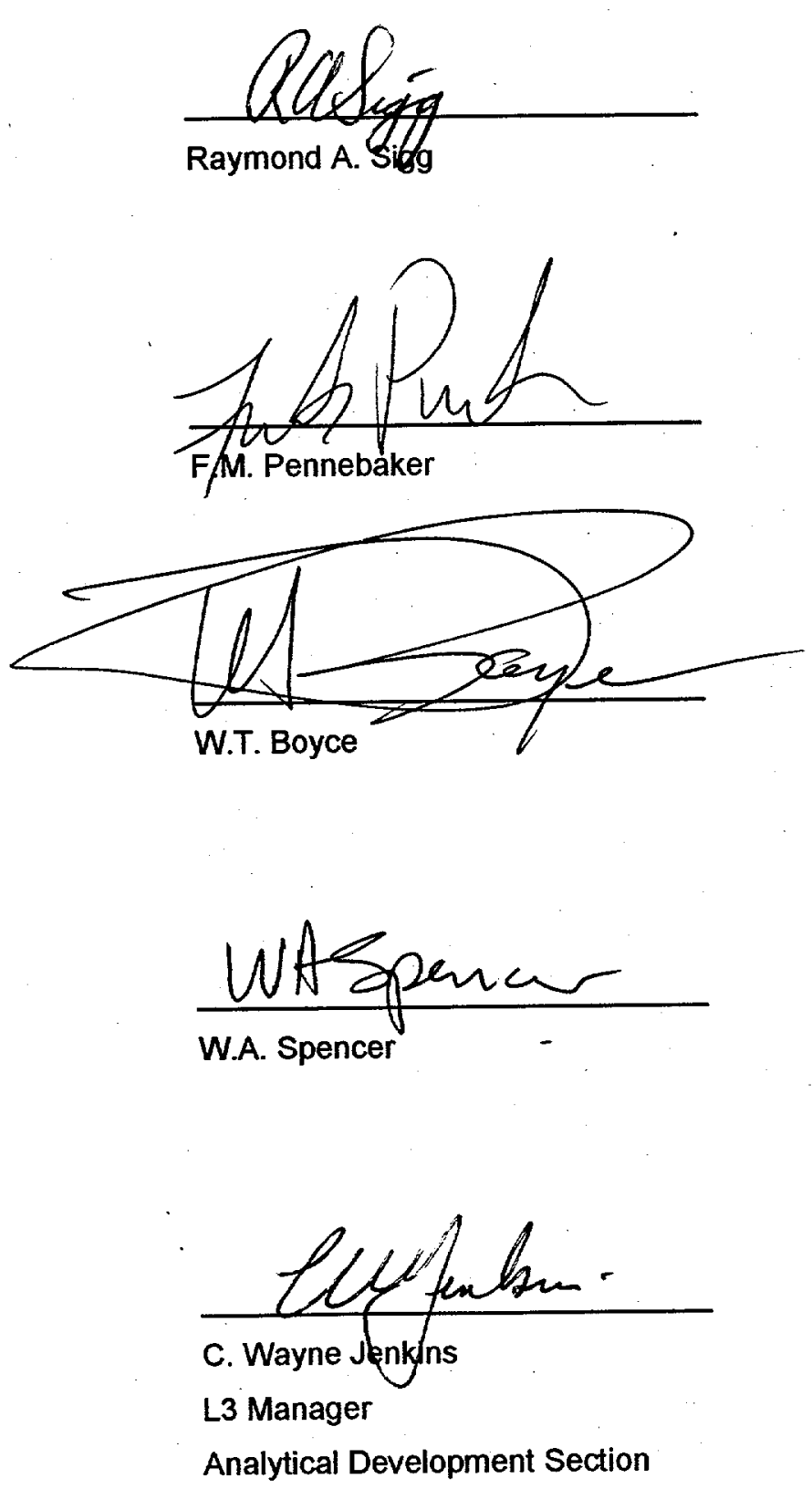
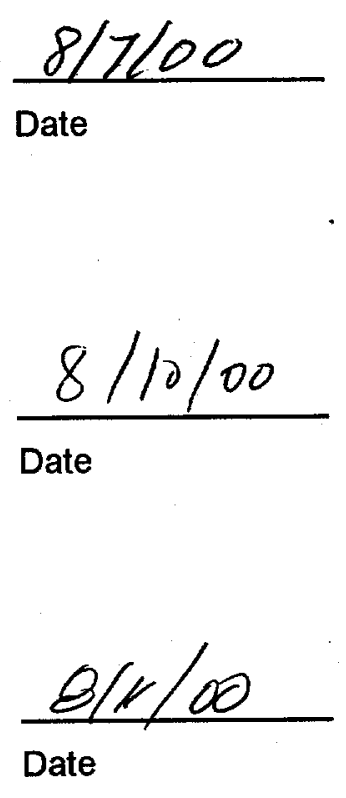

$\frac{818 / 00}{\text { Date }}$

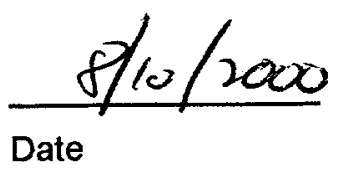

2 


\title{
Supplemental Report: Technetium-99 On-Line Monitoring by Beta Counting for Hanford Supernate Waste Solutions
}

\author{
R.A. Sigg, F.M. Pennebaker, W.T. Boyce, C.S. Nuessle and W.A. Spencer
}

\section{Summary}

SRTC is investigating approaches for near-real-time monitoring of ${ }^{99} \mathrm{Tc}$ at selected points in the proposed pretreatment process for Hanford supernate waste solutions. The desired monitoring points include both the feed to and decontaminated product from a technetium-removal column. A Cs-removal column precedes technetium decontamination in the proposed process. Our earlier report (Ref. 1) showed that

- A simple flow-through beta counting system can easily meet ${ }^{99} \mathrm{Tc}$ detection limit goals for solutions that do not contain interfering radionuclides; however,

- Concentrations of residual interferences were too high in process solutions at the desired monitoring points. That is, technetium can not be measured without additional purification.

In this supplement, ADS evaluated ion exchange cartridges to remove radionuclides that interfere with ${ }^{99} \mathrm{Tc}$ beta measurements. Tests on radioactive standard solutions and on Hanford Envelope B (AZ-102) pretreated process solutions show that ${ }^{99} \mathrm{Tc}$ passes through the cation removal cartridge to an on-line beta counter, and that interfering radionuclides were nearly totally removed. Envelope B solutions included both the process's Csremoved feed to the Tc-removal column and product from the column. Analyses of these solutions before and after the cation exchange cartridge show that the concentration of the primary interference, ${ }^{137} \mathrm{Cs}$, was reduced to about $1 / 250^{\text {th }}$ of the feed concentration.

However, residual activity levels of interfering beta emitters in product from the cation filter were approximately ten times greater than the desired process control concentration level for ${ }^{99} \mathrm{Tc}$. The activity of ${ }^{106} \mathrm{Ru}$ and its short-lived ${ }^{106} \mathrm{Rh}$ daughter were nearly the same in the cation exchange cartridge feed and product solutions. That is, tests on Envelope B solutions show that ${ }^{137} \mathrm{Cs}$ (the primary interference) was greatly reduced, but residual anionic ${ }^{106} \mathrm{Ru} /{ }^{106} \mathrm{Rh}$ would not allow gross beta measurements to succeed.

Sensitivity goals can be met for Envelope B if a more sophisticated liquid scintillation beta spectrometer is used to distinguish $\mathrm{Tc}$ from $\mathrm{Ru}$ in cation-purified solutions. Energy regions outside the region containing most of the ${ }^{99} \mathrm{Tc}$ information ( 40 to $294 \mathrm{keV}$ ) can be used to correct for interferences in Envelope B solutions. Long-term tests are needed to assure that cation exchange and beta spectrometer performances can be sustained.

Similar cation exchange studies were not completed using Hanford Envelope A and Envelope C solutions; however, from studies using radioactive spikes and Envelope $\mathrm{A}$ simulant, cation interference removal is expected to allow direct Tc monitoring for Envelope A. Additional work is needed to access this approach for Envelope C technetium monitoring. 


\section{Introduction}

While a simple flow-through beta counting system can easily meet ${ }^{99} \mathrm{Tc}$ process monitoring goals for solutions free of interfering radionuclides, technetium can not be measured by beta counting process solutions without additional purification (Ref. 1). Concentrations of radionuclides other than technetium are too high in both the feed to and the product from the Tc-removal column to allow technetium determination by beta counting. Several approaches can be taken to provide technetium with fewer contaminants to a beta spectrometer.

Clemson University (Ref. 2) and Pacific Northwest National Laboratory (Ref. 3) evaluated automated radiochemical methods for this application. These relied on selective extraction of technetium from process solutions and subsequent beta counting of the extracted solution. However, our customer believed that the automated methods may be too complex for process monitoring, particularly if the method included an oxidation step to bring technetium to the pertechnetate $(+7)$ oxidation state.

In this phase of the study, SRTC investigated an alternate approach that removes most of the interfering radionuclides while leaving technetium in solution. Since most of the interfering fission and activation products occur as cations and most of the technetium is anionic, a simple in-line cation exchange column was tested. The non-specific cation cartridge was expected to allow technetium to pass through for on-line beta counting while holding back interferences. In a process analyzer, the small cation cartridge could be disposable or could be configured for regeneration between process runs.

\section{Experimental}

\section{Equipment}

In addition to equipment described in the earlier Tc-monitoring report (Ref. 1), the apparatus shown in Figure 1 was configured for this portion of the study. Photographs of the equipment are included in Reference 4 as Figures 1a through 1e. Note that the apparatus was configured to provide basic information on the removal of interferences; a final on-line process instrument would be configured differently. The experimental setup included:

- An ion exchange column. An Omni $3.0 \mathrm{~mm}$ ID by $100 \mathrm{~mm}$ OD microbore column was packed with $0.7 \mathrm{~mL}$ (bed volume) of 50 to 100 mesh Dowex $50 \times 8$ cation exchange resin in the sodium form.

- A sample addition system comprised of:

- A Valco Cheminert 1/16-inch 6-way sampling valve.

- A $\sim 180$ microLiter sample loop.

- A low-flow-rate Fluid Metering, Inc (FMI) Model QV positive displacement pump controlled by an FMI Model V200 stroke rate controller.

- An Alltech Model 426 high-performance liquid chromatography (HPLC) pump to move sample material and other fluids through the column and counters. The pump provides well-controlled low flow rates with minimal 
pulsing; it monitors flow rate and pressure and it provides over-pressure cutoff.

- A flow-through alpha/beta scintillation counter. The Packard Model A525 was described in the earlier report. In this phase of the study, the counter used 300microLiter solid scintillant flow cells packed with either a lithium-loaded glass scintillator or Packard's proprietary SolarScint material. Time-series data were collected using a low-energy window for ${ }^{99} \mathrm{Tc}(20 \mathrm{keV}$ to the endpoint energy, 294 $\mathrm{keV})$ and a region (>294 keV) to monitor higher energy betas. Beta energies for several interfering radionuclides are included in the Results and Discussion section.

- A flow-through gamma-ray spectrometer using:

- A 7.62-cm by $7.62-\mathrm{cm}$ sodium iodide well detector having a $31.7-\mathrm{mm}-$ diameter by 50.8 -mm-deep well.

- A $\sim 0.6 \mathrm{~mL}$ internal volume flow cell that was prepared by coiling $\sim 0.03 \mathrm{~mm}$ ID tubing around a 25.4-mm-diameter plastic spindle. For high efficiency counting, the cell was located in the Nal detector's well.

- An SRTC-developed Sampled Data Spectroscopy multichannel analyzer (Ref. 5).

- A Windows-based PC running SR-developed software that concurrently

- controls the MCA,

- displays time-series data on multiple regions of interest in real time. Gamma-ray regions of interest were set for ${ }^{60} \mathrm{Co},{ }^{137} \mathrm{Cs}$ and ${ }^{241} \mathrm{Am}$,

- displays the most recent gamma-ray spectrum and a running average of recent spectra. Usually the software was configured to average the last three spectra,

- saves raw spectral data for more detailed post processing analysis.

In a typical ion exchange run,

- The FMI pump recirculated test solution through a loop that included a flow-through sampling port.

- The HPLC pump pushed DI water through the sample loop to the cation exchange column and counting cells. The flow rate for most runs was $0.4 \mathrm{~mL} / \mathrm{min}$ which typically affected an 18 psi differential pressure. For reasons discussed later, the pressure increased by $\sim 6 \mathrm{psi}$ as some of the runs progressed.

- The sampling valve was actuated to allow the HPLC pump to divert solution in the sample loop through the IX column and then to the counters. Due to the small sample volume (typically $3 \mathrm{~mL}$ ) used in these experiments, DI water in the sample loop diluted the original sample material by $>35 \%$ after 6 injections.

- After counting, fluids were collected for follow-up analyses. Analytical methods included high purity germanium (HPGe) gamma-ray spectrometry, alpha/beta liquid scintillation spectrometry, ICP-emission- and ICP- mass-spectrometry.

- The HPLC pump was also used to regenerate the column using a sodium nitrate / sodium nitrite solution and to elute radionuclides using nitric acid solutions.

Due to limited space, the ion exchange column and injection apparatus were located in one hood and the HPLC pump and counters were located in an adjacent hood. For this reason, relatively long tubing was needed between the ion exchange column and the 
Rev. 0

August 7, 2000

counters; therefore, the delay between sample injection and beta counter response was about five minutes at the low flow rates $(0.40$ to $0.50 \mathrm{~mL} / \mathrm{min})$ used. Delays would be reduced in a prototype system.

\section{Sample Solutions}

To simplify sample residue handling, initial testing of the apparatus was performed using radioactive standard solutions and samples of SRS waste tank solutions. The SRTC Interim Waste Technology Section provided Hanford solutions. The Hanford materials had been previously processed using cesium- and/or technetium-selective resins. To overcome radiological control concerns, the processed Hanford solutions were diluted with simulant solutions before cation exchange. Table 1 lists radioactive solutions that were tested.

Table 1. Radioactive solutions tested in this phase of the study.

\begin{tabular}{|c|c|}
\hline Solution & Obtained From \\
\hline${ }^{99} \mathrm{Tc}$ & Prepared Gravimetrically \\
\hline $\begin{array}{c}{ }^{60} \mathrm{Co},{ }^{137} \mathrm{Cs},{ }^{241} \mathrm{Am} \\
\text { Diluted using Envelope A Simulant }\end{array}$ & Amersham \\
\hline${ }^{90} \mathrm{Sr} /{ }^{90} \mathrm{Y}$ & NIST SRM-4919G \\
Diluted using Envelope A Simulant & \\
\hline SRS “High Heat" Tank ${ }^{\text { co }}$ & SRS Tank 32H \\
\hline Cs-Removed Envelope B & AZ-102 (Ref. 7) \\
\hline Cs- and Tc-Removed Envelope B & AZ-102 (Ref. 7) \\
\hline
\end{tabular}

1 At the time samples were run for this effort, only the longer-lived radionuclides shown were observed in the aged mixed-gamma standard.

2 The SRS tank solution is expected to behave similarly to Hanford Envelope A.

\section{Results and Discussion}

The following paragraphs discuss results obtained using solutions described in Table 1 .

\section{${ }^{99}$ Tc Standards}

Cation exchange tests on ${ }^{99} \mathrm{Tc}$ standard solutions in Envelope A simulant show that the beta activity passed through the cation column and was counted by the beta counter. Of course, this is the desired response for technetium. Figure 2 demonstrates performance for ${ }^{99} \mathrm{Tc}$; it shows time-series data collected by the flow-through counter after two injections $(0.18 \mathrm{~mL}$ each) of a $10 \mathrm{ppm}$ standard. The flow rate through the $0.30 \mathrm{~mL} \mathrm{Li-}$ 
glass solid scintillant cell was $0.5 \mathrm{~mL} / \mathrm{min}$. The total area above baseline for the peaks in the Tc region of interest is 91573 counts.

Although the injected volume is smaller than the cell void volume and the system was operated in a continuous flow mode, the count rate response is good. A process monitor should

- use a slightly larger sample to completely fill the flow cell, and

- stop flow when the sample reaches the flow cell in order to improve counting statistics/detection limits.

\section{Mixed Gamma-Ray Standard}

In these runs, the cation exchange resin reduced the activities of ${ }^{60} \mathrm{Co},{ }^{137} \mathrm{Cs}$, and ${ }^{241} \mathrm{Am}$ in Envelope A simulant to $\sim 1 / 600^{\text {th }}$ of the activity in feed solution exchange resin. Figure 3 shows data for Envelope A simulant spiked with the mixed gamma-ray (Co, Cs and Am) standard. One trace in the beta time-series data shows a peak when the ion exchange column is bypassed. The lower trace (red) shows residual activity following removal by ion exchange. Radionuclide-specific values in the table were obtained by HPGe gammaray spectrometry. The HPLC pump flow rate for this solution and for the remaining solutions was $0.4 \mathrm{~mL} / \mathrm{min}$.

${ }^{90} \mathrm{Sr} /{ }^{90} \mathrm{Y}$

Injections of ${ }^{90} \mathrm{Sr} /{ }^{90} \mathrm{Y}$ in Envelope A simulant gave different results. Figure 4 shows response of the SolarScint detector when the ion exchange column was bypassed. Note in the earlier figures that beta count rates returned to baseline after the injected peak passed through the counter. However, the response did not return to baseline following ${ }^{90} \mathrm{Sr}$ injection. The injected material was pushed through the system using deionized (DI) water. Continued rinsing with DI water did not remove the activity.

The count rate returned to baseline when the HPLC-pumped fluid was changed to $2 \mathrm{M}$ nitric acid. These data suggest that the crushed scintillator flow cell acted as a filter and accumulated some strontium as particulate matter (likely as carbonates) from the injected basic solution. In this and in all later tests, the accumulated strontium was rapidly removed using nitric acid. Had the experimental system included an in-line filter before the counter, the accumulation likely would have been avoided.

Figure 4 shows beta detector response following injection of the same $\mathrm{Sr} / \mathrm{Y}$ solution after decontamination using the cation exchange resin. Little if any activity was observed after cation removal. Though the peak is weak, $>\sim 97 \%$ of the activity was removed.

\section{SRS Tank $32 H$ Solution}

SRS Tank $32 \mathrm{H}$ is similar to Hanford's Envelope A solutions. Figures $5 \mathrm{a}$ and $5 \mathrm{~b}$ contain gamma-ray and beta-scintillation data respectively for two bypass injections. The cation resin removed all activity observed by beta scintillation (Figure $5 \mathrm{c}$ ). The flow-through 
gamma-ray counter did not detect activity in the sample filtered by the cation-exchange cartridge. The sample used for these injections had been diluted for other analytical work using dilute nitric acid.

\section{Cs-Removed Envelope B}

The SRTC Interim Waste Technology Section provided samples of Hanford Envelope B solution (AZ-102) that had been processed using the proposed cesium-removal resin. As shown in Table 2 below, the sample still had appreciable ${ }^{137} \mathrm{Cs}$ activity. Three injections were made directly into the beta scintillation counting system. An additional three injections were made through the cation exchange column. Figures $6 \mathrm{a}$ and $6 \mathrm{~b}$ present gamma-ray and beta-scintillation time-series data for two feed solution injections. Timeseries beta scintillation results for two cation exchange injections are shown in Figure 6c. Integrated time-series beta results for the injections that bypass the cation column and for injections passing through the column give 40747 and 3137 counts / injection, respectively; that is, the cation resin reduced flow cell gross beta counts to $1 / 13^{\text {th }}$ of the feed solution.

The flow-through gamma-ray system did not detect activity in cation decontaminated material. Upon completion of the runs, vials containing bypass (feed) and cation exchanged sample solution were analyzed by high-resolution gamma-ray spectrometry.

Table 2. Radionuclide activities observed by high resolution gamma-ray spectrometry in cation exchange resin feed and product solutions using Envelope B "Cs-removed" solutions.

\begin{tabular}{|c|c|c|c|}
\hline Radionuclide & $\begin{array}{c}\text { Cation Column } \\
\text { Feed } \\
\mu \mathrm{Ci} / \text { injection }\end{array}$ & $\begin{array}{c}\text { Cation Column } \\
\text { Product } \\
\mu \mathrm{Ci} / \text { injection }\end{array}$ & $\begin{array}{c}\text { Cation Column } \\
\text { Feed to Product } \\
\text { Ratio }\end{array}$ \\
\hline${ }^{106} \mathrm{Ru} /{ }^{106} \mathrm{Rh}$ & $1.57 \mathrm{E}-04$ & $1.07 \mathrm{E}-04$ & 1.51 \\
\hline${ }^{137} \mathrm{Cs}$ & $2.88 \mathrm{E}-03$ & $<7.20 \mathrm{E}-06$ & $>400$ \\
\hline
\end{tabular}

The table shows that ${ }^{137} \mathrm{Cs}$ was the dominant gamma-ray-emitting nuclide in the feed solution, though ${ }^{106} \mathrm{Ru} /{ }^{106} \mathrm{Rh}$ is also present. However, after the cation resin reduced the ${ }^{137} \mathrm{Cs}$ interference by several orders of magnitude, ${ }^{106} \mathrm{Ru} /{ }^{106} \mathrm{Rh}$ was the primary gammaray emitter remaining in the cation exchanged product. The fact that the $\mathrm{Ru} / \mathrm{Rh}$ concentration was only slightly reduced provides strong evidence that it, like technetium, is anionic in Envelope B.

Separate liquid scintillation samples were prepared using aliquots of solutions collected from these runs. Beta spectra, gathered using a Packard TR-2550AB LSC counter, for the direct injection and cation exchanged solutions (Figures $7 \mathrm{a}$ and $7 \mathrm{~b}$, respectively) show that: 
- The beta spectrum for injections bypassing the cation exchange column is a composite for all the beta emitters in the feed solution.

- ${ }^{106} \mathrm{Ru}$ (end-point energy: $40 \mathrm{keV}$ ).

- ${ }^{99} \mathrm{Tc}$ (end-point energy: $294 \mathrm{keV}$ ).

- Components having beta energies higher than ${ }^{99} \mathrm{Tc}$ include

- ${ }^{90} \mathrm{Sr}$ (endpoint energy $546 \mathrm{keV}$ )

- ${ }^{137} \mathrm{Cs}$ (endpoint energy $512 \mathrm{keV}$, and several conversion electrons from 624 to $662 \mathrm{keV})$,

- ${ }^{90} \mathrm{Y}$ (end-point energy: $2282 \mathrm{keV}$ ), and

- ${ }^{106} \mathrm{Rh}$ (end-point-energy: $3540 \mathrm{keV}$ ).

Since beta spectra are continuous, the higher energy beta emitters raise the counting background for ${ }^{99} \mathrm{Tc}$.

- The cation-purified spectrum appears to be comprised of three main components:

- a low energy ${ }^{106} \mathrm{Ru}$ (end-point energy $40 \mathrm{keV}$ ),

- ${ }^{99} \mathrm{Tc}$ (end-point energy: $294 \mathrm{keV}$ ), and

- the short-lived $(30 \mathrm{sec}){ }^{106} \mathrm{Rh}$ daughter of ${ }^{106} \mathrm{Ru}$. A small amount of ${ }^{90} \mathrm{Sr}{ }^{90} \mathrm{Y}$ may also remain.

- ${ }^{99} \mathrm{Tc}$ is clearly visible in the beta spectrum of the cation-removed sample, but it can not be distinguished in the feed sample.

Table 3 presents results obtained by integrating the beta spectra, shown in the figures, over several energy windows.

Table 3. Beta spectra of cation exchange resin feed and product solutions using Envelope B "Cs-removed" solutions.

\begin{tabular}{|c|c|c|c|c|}
\hline $\begin{array}{c}\text { Liquid Scintillation } \\
\text { Beta Spectrum } \\
\text { Energy Region }\end{array}$ & $\begin{array}{c}\text { Cation Column } \\
- \text { Feed } \\
\text { Counts / 10 min }\end{array}$ & $\begin{array}{c}\text { Cation Column } \\
\text { Product } \\
\text { Counts / 10 min }\end{array}$ & $\begin{array}{c}\text { Feed to Cation } \\
\text { Exchanged Ratio }\end{array}$ & $\begin{array}{c}\text { Radionuclides } \\
\text { Included in the } \\
\text { Energy Region }\end{array}$ \\
\hline Full Spectrum & 84098 & 6451 & 13 & All \\
\hline 0 to $40 \mathrm{keV}$ & 11444 & 2175 & 5.3 & $\begin{array}{c}{ }^{106} \mathrm{Ru}+\text { all higher- } \\
\text { energy beta }\end{array}$ \\
\hline 40 to $294 \mathrm{keV}$ & 44461 & 3578 & 12 & $\begin{array}{c}99 \mathrm{Tc}+\mathrm{Cs}, \mathrm{Sr}, \mathrm{Y}, \mathrm{Rh} \\
\text { interferences }\end{array}$ \\
\hline$>294 \mathrm{keV}$ & 28193 & 698 & 40 & $\begin{array}{c}{ }^{90} \mathrm{Sr},{ }^{137} \mathrm{Cs}+\mathrm{Y}, \mathrm{Rh} \\
\text { interferences }\end{array}$ \\
\hline$>750 \mathrm{keV}$ & 10157 & 432 & 23 & ${ }^{90} \mathrm{Y},{ }^{106} \mathrm{Rh}$ \\
\hline
\end{tabular}

Comparisons of beta scintillation data show that the cation resin reduced the total beta activity to $1 / 13^{\text {th }}$ of the activity in the feed.

Almost all of the counts in the 40- to 294-keV region of the cation product LSC spectrum are due to ${ }^{99} \mathrm{Tc}$. This was determined from knowledge of 1) concentration of ${ }^{99} \mathrm{Tc}$ in $\mathrm{AZ}$ 102 filtrate (Ref. 7, Table 1), 2) dilution of Cs-removed Envelope B solution before these tests, 3) injection volume, 4) LSC aliquots sizes, and 5) LSC counter efficiency in the 
energy region of interest. The count rate expected after these corrections was slightly higher than the observed rate.

Upon completion of the cation exchange run, the flow cell was washed with $4 \mathrm{M}$ nitric acid. The wash solution was collected for beta spectrometry. The beta energy spectrum is presented in Figure 7c. The spectrum supports our earlier statement that the radionuclide responsible for causing a higher gross beta background after the injected material passes through the counter is ${ }^{90} \mathrm{Sr}$; the LSC spectrum has the appropriate shape for ${ }^{90} \mathrm{Sr}$ and its partially ingrown ${ }^{90} \mathrm{Y}$ daughter.

These scoping data suggest that a flow through beta counter could be developed to measure ${ }^{99} \mathrm{Tc}$ in Envelope B feed to the Hanford process's Tc-removal column if the process monitor:

- Uses an analytical-scale cation exchange column to remove most interferences from samples taken from the process stream,

- Prefilters samples before counting to remove fine particulates,

- Used a liquid scintillation flow cell to

- Avoid accumulation of activity in the cell, and

- Provide beta energy spectra to help discriminate ${ }^{99} \mathrm{Tc}$ from interferences.

\section{Cs- and Tc-Removed Emvelope B}

SRTC also conducted tests using BNFL Envelope B solutions that had previously been decontaminated using the proposed Cs-removal and Tc-removal resins for the Hanford effort. Time-series data from flow-through counters are shown in Figure 8. Figures 8a and $8 \mathrm{~b}$ are for injection of feed solution to gamma-ray and beta scintillation detectors, respectively. Flow-through beta scintillation data for a cation-exchanged injection are shown in Figure 8c.

Upon completion of the runs, vials containing bypass (feed) and cation exchanged sample solution were analyzed by high-resolution gamma-ray spectrometry.

Table 4. Radionuclide activities observed by high-resolution gamma-ray spectrometry in cation exchange resin feed and product solutions using Envelope B "Cs-removed" solutions.

\begin{tabular}{|c|c|c|c|}
\hline Radionuclide & $\begin{array}{c}\text { Cation Column } \\
\text { Feed } \\
\mu \mathrm{Ci} / \text { injection }\end{array}$ & $\begin{array}{c}\text { Cation Column } \\
\text { Product } \\
\mu \mathrm{Ci} / \text { injection }\end{array}$ & $\begin{array}{c}\text { Cation Column } \\
\text { Feed to Product } \\
\text { Ratio }\end{array}$ \\
\hline${ }^{106} \mathrm{Ru} /{ }^{106} \mathrm{Rh}$ & $6.43 \mathrm{E}-04$ & $3.90 \mathrm{E}-04$ & 1.6 \\
\hline${ }^{137} \mathrm{Cs}$ & $1.75 \mathrm{E}-02$ & $5.87 \mathrm{E}-05$ & 300 \\
\hline
\end{tabular}

${ }^{137} \mathrm{Cs}$ was the dominant gamma-ray emitting nuclide in the Cs- and Tc-removed feed solution, though ${ }^{106} \mathrm{Ru} /{ }^{106} \mathrm{Rh}$ was also present. However, after the cation resin reduced the ${ }^{137} \mathrm{Cs}$ interference to $\sim 1 / 300^{\text {th }}$ of the feed concentration, ${ }^{106} \mathrm{Ru} /{ }^{106} \mathrm{Rh}$ became the main 
gamma-ray emitter in the cation exchanged product. The fact that the $\mathrm{Ru} / \mathrm{Rh}$ concentration was only slightly reduced provides additional evidence that it is present as an anionic complex in Envelope B.

Separate liquid scintillation samples were prepared using aliquots of solutions collected from these runs. Beta spectra, gathered using a Packard TR-2550AB LSC counter, for the bypass and cation exchanged (Figures $9 a$ and $9 b$, respectively) show that:

- The beta spectrum for injections bypassing the cation exchange column shows a peak in the 600 - to $700-\mathrm{keV}$ region from ${ }^{137} \mathrm{Cs}$ conversion electrons. The visible high-energy components (above the Cs peak) include ${ }^{90} \mathrm{Y}$ (end-point energy: 2282 $\mathrm{keV}$ ) and ${ }^{106} \mathrm{Rh}$ (end-point-energy: $3540 \mathrm{keV}$ ). The region below the peak includes ${ }^{90} \mathrm{Sr}$ and ${ }^{99} \mathrm{Tc}$, and it contains lower energy portions of $\mathrm{Cs}, \mathrm{Rh}, \mathrm{Ru}$, and $\mathrm{Y}$ beta distributions.

- The cation-purified spectrum is comprised of several components:

- a low energy ${ }^{106} \mathrm{Ru}$ (end-point energy $40 \mathrm{keV}$ ),

- the high-energy, short-lived (30 sec) ${ }^{106} \mathrm{Rh}$ daughter of ${ }^{106} \mathrm{Ru}$,

- it may contain a small amount of ${ }^{90} \mathrm{Sr}$, and

- ${ }^{137} \mathrm{Cs}$, though the activity measured by gamma spectrometry shows cesium's contribution would be small.

- Since ${ }^{99} \mathrm{Tc}$ had been previously removed from the feed, the fact that ${ }^{99} \mathrm{Tc}$ is not visible in the beta spectrum is not surprising.

The beta spectra shown in the Figures $9 a$ and $9 b$ were integrated over the same energy regions described for Cs-removed Envelope B feed.

Table 5. LSC beta spectra of cation exchange resin feed and product solutions using Envelope B decontaminated ("Cs- and Tc-removed") solutions.

\begin{tabular}{|c|c|c|c|c|}
\hline $\begin{array}{c}\text { Liquid Scintillation } \\
\text { Beta Spectrum } \\
\text { Energy Region }\end{array}$ & $\begin{array}{c}\text { Cation Column } \\
\text { Feed } \\
\text { Counts } / 10 \mathrm{~min}\end{array}$ & $\begin{array}{c}\text { Cation Column } \\
\text { Product } \\
\text { Counts } / 10 \mathrm{~min}\end{array}$ & $\begin{array}{c}\text { Cation Column } \\
\text { Feed to Product } \\
\text { Ratio }\end{array}$ & $\begin{array}{c}\text { Radionuclides } \\
\text { Included in the } \\
\text { Energy Region }\end{array}$ \\
\hline Full Spectrum & 504257 & 13394 & 38 & All \\
\hline 0 to $40 \mathrm{keV}$ & 57516 & 5342 & 11 & $\begin{array}{c}{ }^{106} \mathrm{Ru}+\text { all higher- } \\
\text { energy beta }\end{array}$ \\
\hline 40 to $294 \mathrm{keV}$ & 254189 & 2704 & 94 & $\begin{array}{c}{ }^{99} \mathrm{Tc}+\mathrm{Cs}, \mathrm{Sr}, \mathrm{Y}, \mathrm{Rh} \\
\text { interferences }\end{array}$ \\
\hline$>294 \mathrm{keV}$ & 192615 & 5299 & 36 & $\begin{array}{c}{ }^{90} \mathrm{Sr},{ }^{137} \mathrm{Cs}+\mathrm{Y}, \mathrm{Rh} \\
\text { interferences }\end{array}$ \\
\hline$>750 \mathrm{keV}$ & 70606 & 3209 & 22 & ${ }^{90} \mathrm{Y},{ }^{106} \mathrm{Rh}$ \\
\hline
\end{tabular}

The cation resin reduced the total beta activity to $\sim 1 / 40^{\text {th }}$ of the activity in the feed, and interferences were reduced even more significantly in ${ }^{99} \mathrm{Tc}^{\prime} \mathrm{s} 40$ to $294 \mathrm{keV}$ region. Note, the Cs-removed sample (Table 3 ) had a larger dilution ( $\sim$ factor of 6$)$ than the Cs- and Tc-removed sample. 
Other analytical efforts determined the ${ }^{99} \mathrm{Tc}$ concentration in $\mathrm{AZ}-102$ pretreatment test solutions (Ref.7). Using that information and from knowledge of :

- dilution of Cs- and Tc-removed Envelope B solution before cation column tests,

- injection volumes,

- LSC aliquots sizes, and

- LSC counter efficiency in energy region of interest,

${ }^{99} \mathrm{Tc}$ is expected to contribute approximately 800 counts to the $40-$ to $294-\mathrm{keV}$ region in this Tc-removed solution. Approximately $70 \%$ of the counts in the 40 - to $294-\mathrm{keV}$ region of the LSC spectrum are due to interfering activities that remain after ion . exchange.

Table 6 shows detection limits that could be achieved if this interference background were stable throughout a 40 -hour process run. The table includes data for a liquid scintillation instrument giving reasonable energy resolution for beta spectra, and it includes a column for a gross beta counter (no energy discrimination). It assumes that a $0.3-\mathrm{mL}$ sample was purified and counted in a stop-flow mode.

Table 6. Detection limits for ${ }^{99} \mathrm{Tc}$ in cation-exchange-purified product solution if interference levels are constant.

\begin{tabular}{|c|c|c|}
\hline $\begin{array}{c}\text { Count Time } \\
(\mathrm{min})\end{array}$ & $\begin{array}{c}\text { Beta Spectrometer } \\
{ }^{99} \mathrm{Tc} \text { Detection Limit } \\
\mu \mathrm{g} / \mathrm{mL}\end{array}$ & $\begin{array}{c}\text { Gross Beta } \\
{ }^{99} \mathrm{Tc} \text { Detection Limit } \\
\mu \mathrm{g} / \mathrm{mL}\end{array}$ \\
\hline 5 & 0.25 & 1.18 \\
\hline 10 & 0.17 & 0.84 \\
\hline 30 & 0.10 & 0.49 \\
\hline
\end{tabular}

Because it is unreasonable to assume interference levels remain constant through a 40hour process run, other information would be needed to determine the interference background. The shape of the beta spectra both below and above the 40- to 294-keV region can be used in a several component model to correct for variations in interference levels, and a more sensitive flow-through gamma-ray instrument would provide additional data on residual ${ }^{137} \mathrm{Cs}$ and ${ }^{106} \mathrm{Ru} /{ }^{106} \mathrm{Rh}$ activities.

Analyses of Cs- and Tc-removed solutions showed that residual ${ }^{137} \mathrm{Cs}$ and ${ }^{106} \mathrm{Ru} /{ }^{106} \mathrm{Rh}$ (and possibly ${ }^{90} \mathrm{Sr}{ }^{90} \mathrm{Y}$ ) activity levels would not permit direct measurement of ${ }^{99} \mathrm{Tc}$ at levels desired for process control unless supplemental information about the interference levels is available. This need for supplemental information is another driver for using liquid scintillation flow cells; the quality of the beta spectra is better with liquid scintillators than with crushed solids. This is because the solution to be counted is homogeneously mixed with liquid scintillant and light scattering effects are less than with heterogeneous crushed solid scintillants. The flow-through beta counter's software does not permit concurrent collection of time-series and energy spectral data. 
Although the flow-through gamma-ray system did not detect activity in cation decontaminated material, high-resolution gamma-ray spectrometry was able to measure the $\mathrm{Cs}$ and $\mathrm{Ru}$ content. Therefore, the flow-through gamma-ray counter should provide useful information after cation exchange, if its sensitivity is improved. In these runs, time-series gamma-ray data were collected every 15 seconds, and the full energy spectrum was saved for each time interval. Figure 10 shows the spectra obtained by summing all of the individual spectra for times when an injected sample would pass through the counter. ${ }^{137} \mathrm{Cs}$ is clearly visible at $662 \mathrm{keV}$ in the feed (bypass) solution (Figure 10a), but - in the cation exchanged sum spectrum (Figure 10b) - the activity of ${ }^{137} \mathrm{Cs}$ and ${ }^{106} \mathrm{Ru} /{ }^{106} \mathrm{Rh}$ is too low relative to detector background to obtain a clear signal using diluted feed (Dilution Factor: 7.9). It should be possible to observe ${ }^{106} \mathrm{Ru} /{ }^{106} \mathrm{Rh}$ and ${ }^{137} \mathrm{Cs}$ using the flow-through gamma-ray system with

- undiluted feed,

- better detector shielding, and

- longer counting in a stop-flow mode or a larger-volume flow cell.

Aliquots of cation feed and product solutions, from the same solutions used for LSC sample preparations, were analyzed by ICP mass spectrometry (ICP-MS). Table 7 gives cation feed to product solution ratios observed by that technique and it presents several ratios from nuclear counting methods for comparison. In the case of ${ }^{133} \mathrm{Cs}$, ICP ratios differed significantly from counting due to ICP instrument backgrounds. Dilution effects, which were discussed in the experimental section of this report, cause these tabulated feed to product ratios to be about $50 \%$ higher than would have been observed with fresh feed for each injection.

Table 7. Cation exchange column feed to product concentration ratios determined by ICP-mass spectrometry. Data for several nuclear measurements are included for comparison.

\begin{tabular}{|c|c|c|c|}
\hline Isotopes & $\begin{array}{c}\text { Cation Column } \\
\text {-Feed to Product } \\
\text { ICP-MS Ratio }\end{array}$ & $\begin{array}{c}\text { Cation Column } \\
\text { Feed to Product } \\
\text { Counting Ratio }\end{array}$ & Radionuclides \\
\hline${ }^{89} \mathrm{Y}$ & 11 & $22+-2 \% 1 \sigma$ & ${ }^{90} \mathrm{Y}+{ }^{106} \mathrm{Rh}$ (LSC) \\
\hline${ }^{133} \mathrm{Cs}{ }^{*}$ & -2 & $300+-10 \% 1 \sigma$ & ${ }^{137} \mathrm{Cs}$ (gamma) \\
\hline${ }^{85,87} \mathrm{Rb}$ & 55 & - & - \\
\hline${ }^{95,97,98,100} \mathrm{Mo}$ & 2.2 & - & - \\
\hline${ }^{101,102,104} \mathrm{Ru}$ & 1.6 & $1.35+-18 \% 1 \sigma$ & ${ }^{106} \mathrm{Ru}\left({ }^{106} \mathrm{Rh}\right.$ gamma) \\
\hline${ }^{103} \mathrm{Rh}$ & 1.5 & - & - \\
\hline${ }^{110,111} \mathrm{Cd}$ & 2.0 & - & - \\
\hline${ }^{121,123} \mathrm{Sb}$ & 10 & - & - \\
\hline${ }^{238} \mathrm{U}$ & $>100$ & - & \\
\hline
\end{tabular}

* Instrument background interference. 


\section{CONCLUSIONS}

These studies focused on the application of a cation exchange cartridge to remove most residual interferences from process solutions. The studies show promising results and provide guidance on modifications that should be made to a prototype unit. Long-term tests need to be conducted to assure that performance can be sustained through a 40-hour production run.

Some of the changes that need to be incorporated include:

- Use of a prefilter to remove particulate activity before beta spectroscopy.

- Both time-series and LSC-spectral data should be collected concurrently.

- Information in beta spectra should be used to resolve ${ }^{99} \mathrm{Tc}$ from interferences that remain after cation exchange.

- Larger volume samples should be injected to fill the counting cell.

- Samples should be counted in a stop-flow mode to improve counting statistics.

Further studies are needed to:

- Characterize inorganic cation exchange resins in order to simplify disposal.

- Define appropriate regeneration parameters, if cation cartridge regeneration is preferable to disposal.

- Appropriately size the cation column for injections across a 40-hour process run.

- Determine technetium removal by cation resin as a function of technetium's oxidation state. 


\section{REFERENCES}

1. R.A. Sigg, "Technetium-99 On-Line Monitoring Studies Employing Beta Counting," BNF-003-98-0200, Jan., 2000.

2. T. DeVol, A. Paulenova and J.E. Roane, “On-Line/At-Line Technetium Monitor Using Scintillating Ion Exchange Resins for the Savannah River Site," WSRC-TR-9900247 (1999).

3. O.B. Egorov and D.E. Kurath, "Automated 99Tc Analysis in AW-101 and AN-107 "Diluted Feed" Matrices," BNFL-RPT-020 Rev. 0, Jan., 2000.

4. W.A. Spencer, F.M. Pennebaker, D.J. McCabe, R.A. Sigg and C.W. Jenkins, "Supplemental Report: Application of Emission Spectroscopy to Monitoring Technetium in Hanford Supernate Waste Solutions," BNF-003-98-0233.

5. D.M.C. Odell, B.S. Bushart, L.J. Harpring, F.S. Moore and T.N.Riley, "Zero Deadtime Spectroscopy without Full Charge Collection," WSRC-MS-98-00266, May, 1998.

6. N.M. Hassan, D.J. McCabe and W.D. King, "Small-Scale Ion Exchange Removal of Cesium and Technetium from Hanford Tank 241-AN-103," BNF-003-98-0146 Revision 1, April, 2000.

7. N.M. Hassan, D.J. McCabe, W.D. King, and M.L. Crowder, "Small-Scale Ion Exchange Removal of Cesium and Technetium from Hanford Tank 241-AZ-102," BNF-003-98-0146 Revision 0, April, 2000. 
BNF-003-98-0285

Rev. 0

August 7, 2000

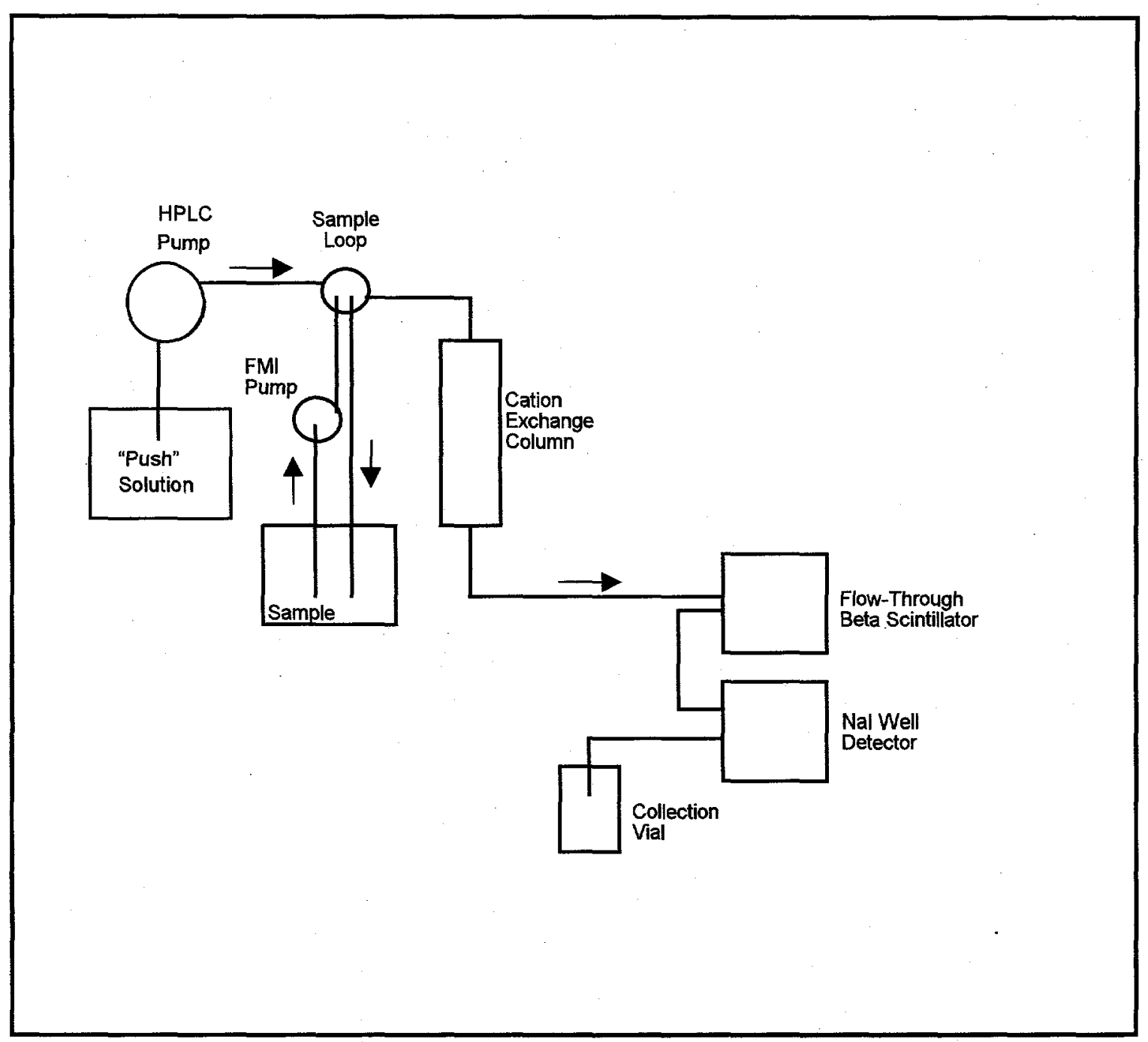

Figure 1. Block diagram of the experimental cation exchange, on-line beta scintillation and gamma counting apparatus. 


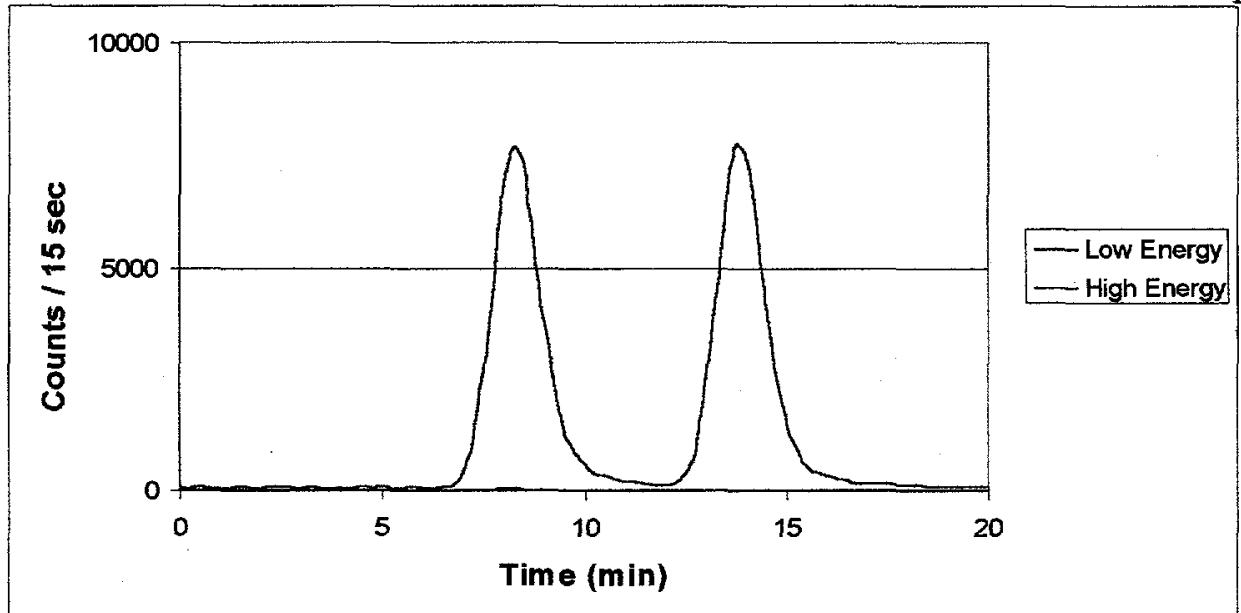

Rev. 0

August 7, 2000

Figure 2. Flow-through beta counting results for ${ }^{99} \mathrm{Tc}$ after cation exchange. The low energy region is from 20 to $294 \mathrm{keV}$, and the high energy region is $>294 \mathrm{keV}$.

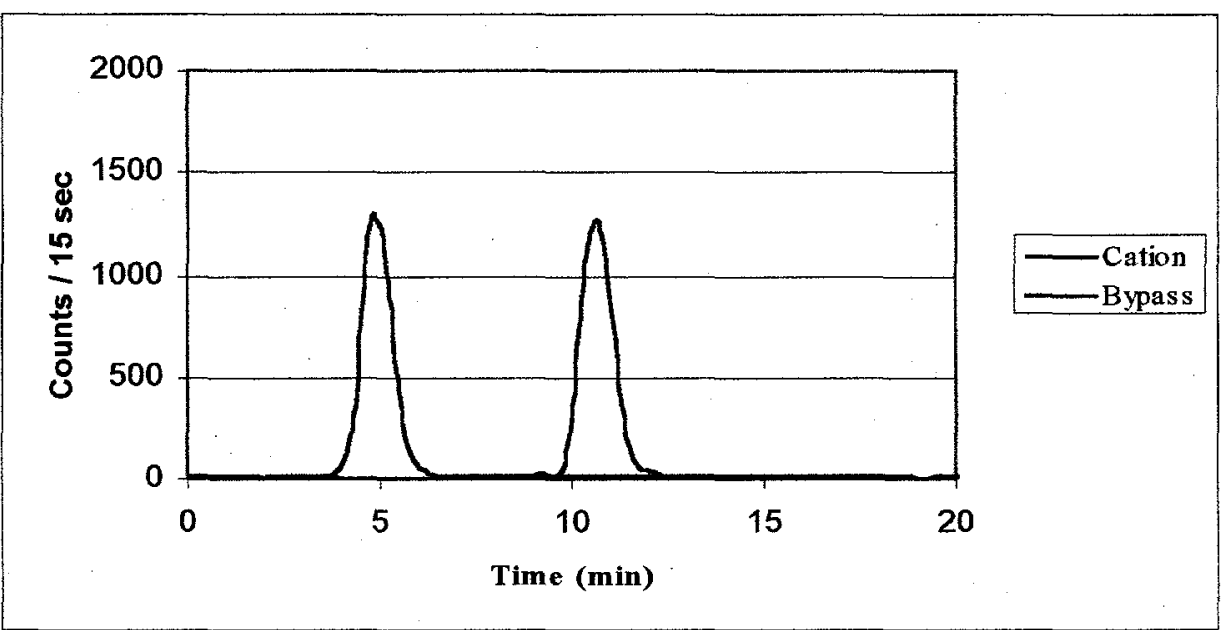

Figure 3. Flow-through beta counting results for a mixed gamma standard without cation exchange(bypass) and after cation exchange, two injections each.

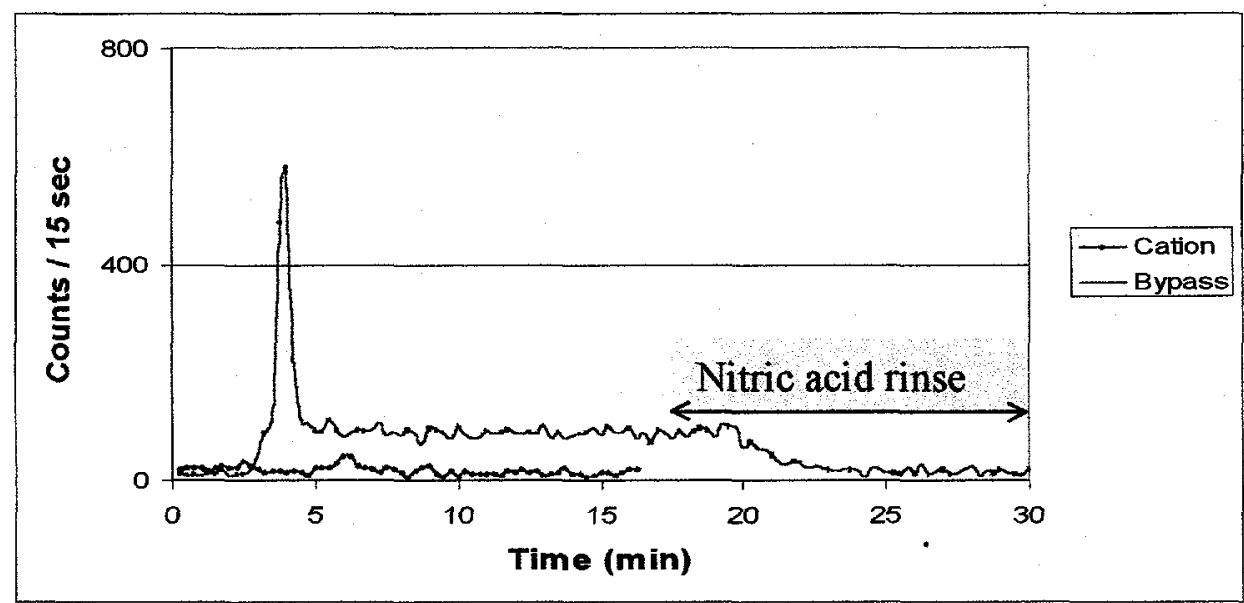

Figure 4. Flow through beta counting of ${ }^{90} \mathrm{Sr} /{ }^{90} \mathrm{Y}$ with and without cation exchange. A nitric acid rinse cleaned the counting cell after the bypass run. 
BNF-003-98-0285

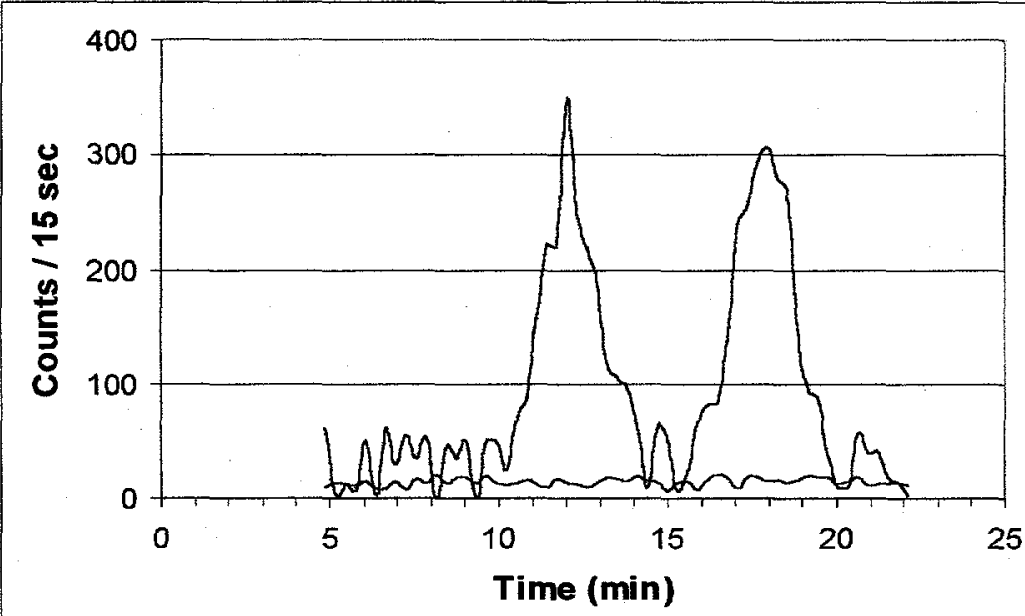

Figure 5a

Rev. 0

August 7, 2000
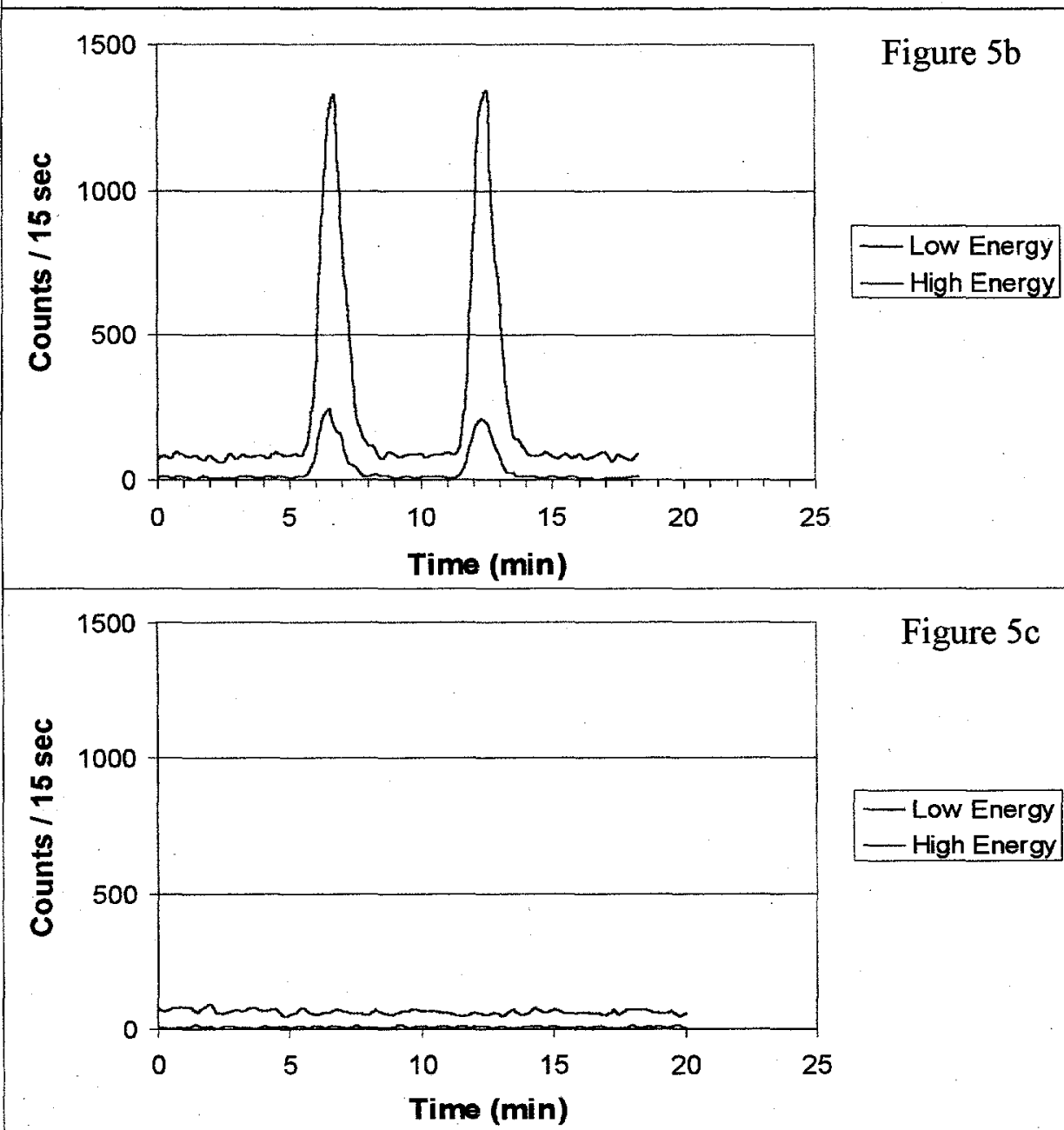

Figure 5c

- Low Energy - High Energy

Figure 5. SRS Tank $32 \mathrm{H}$ sample injections.

A. Gamma-ray data for two bypass injections.

B. Beta scintillation data for two injections bypassing cation exchange.

C. Beta scintillation data for two cation exchange injections. 

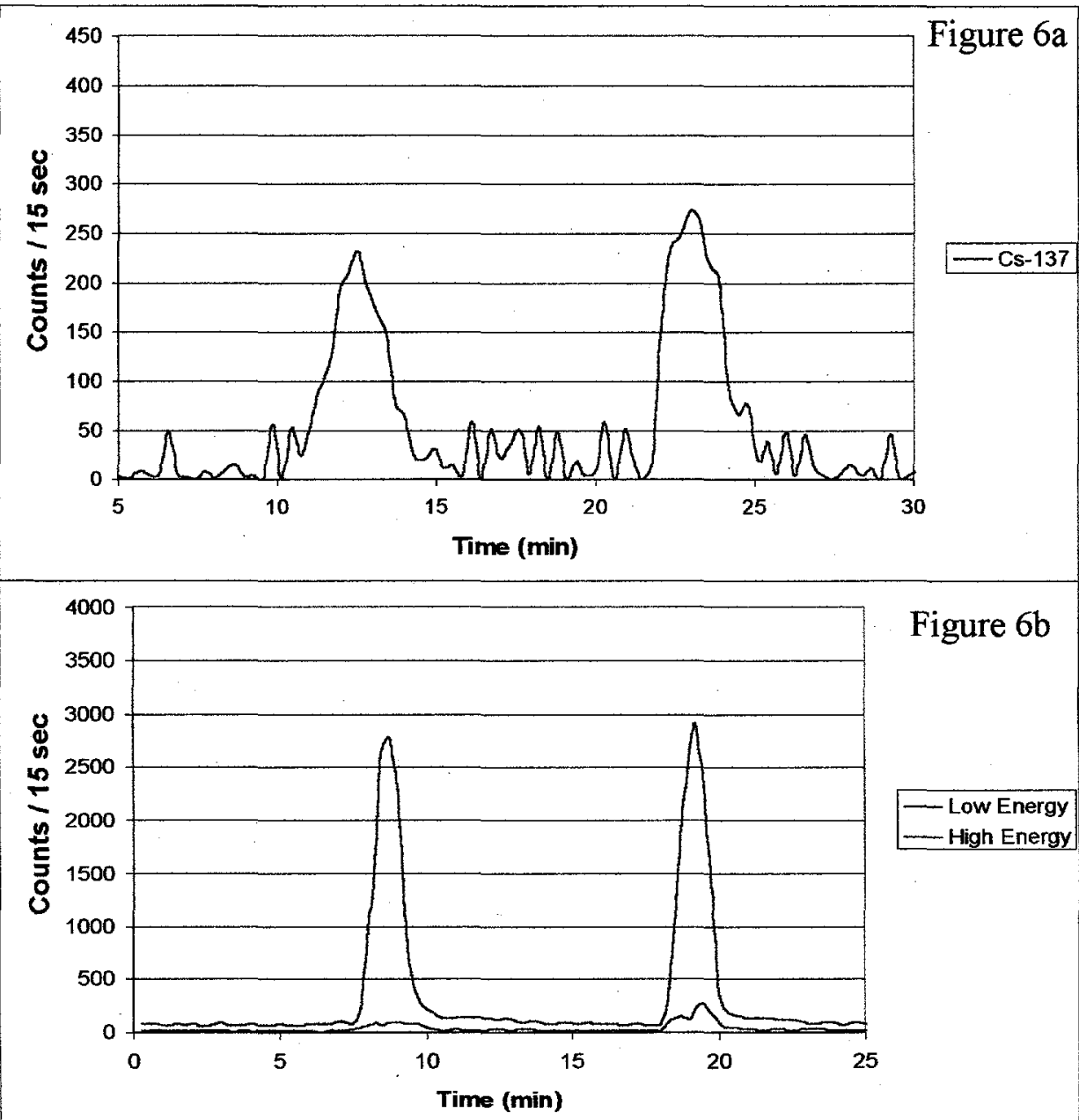

Figure $6 b$

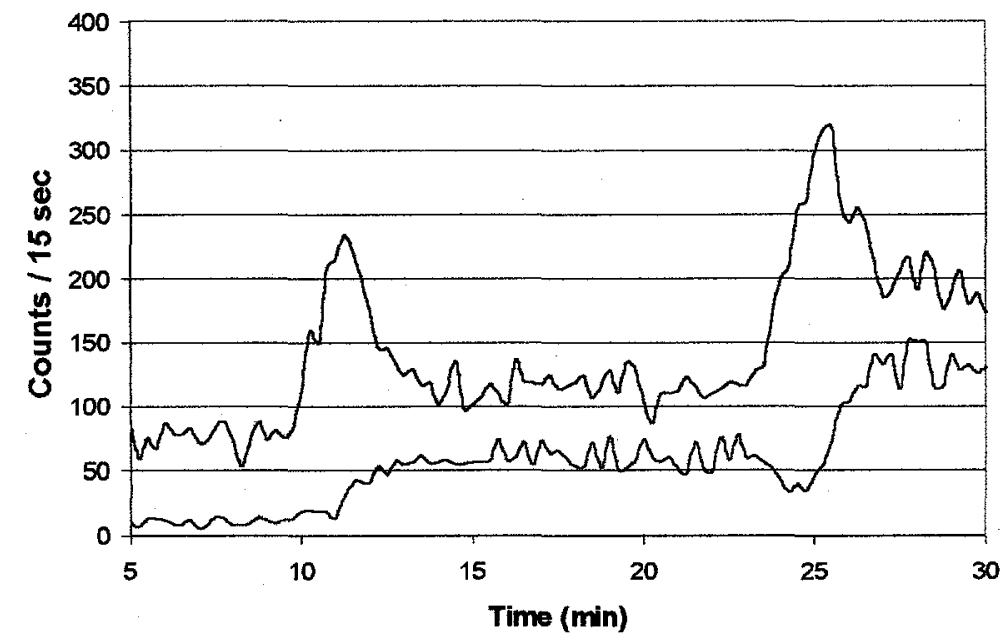

Figure 6c

- Low Energy - High Energy

5
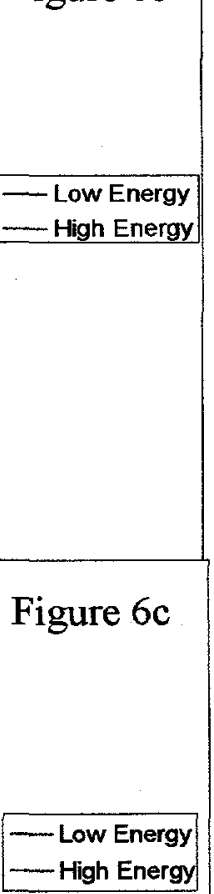

Figure 6. Hanford Cs-removed Envelope B solution (AZ-102).

A. Gamma-ray data for two bypass injections.

B. Beta scintillation data for two injections bypassing cation exchange.

C. Beta scintillation data for two cation exchange injections.

Note the change in vertical scale between figures $\mathrm{a}, \mathrm{b}$ and $\mathrm{c}$ and baseline shifts in Fig. 6c. 


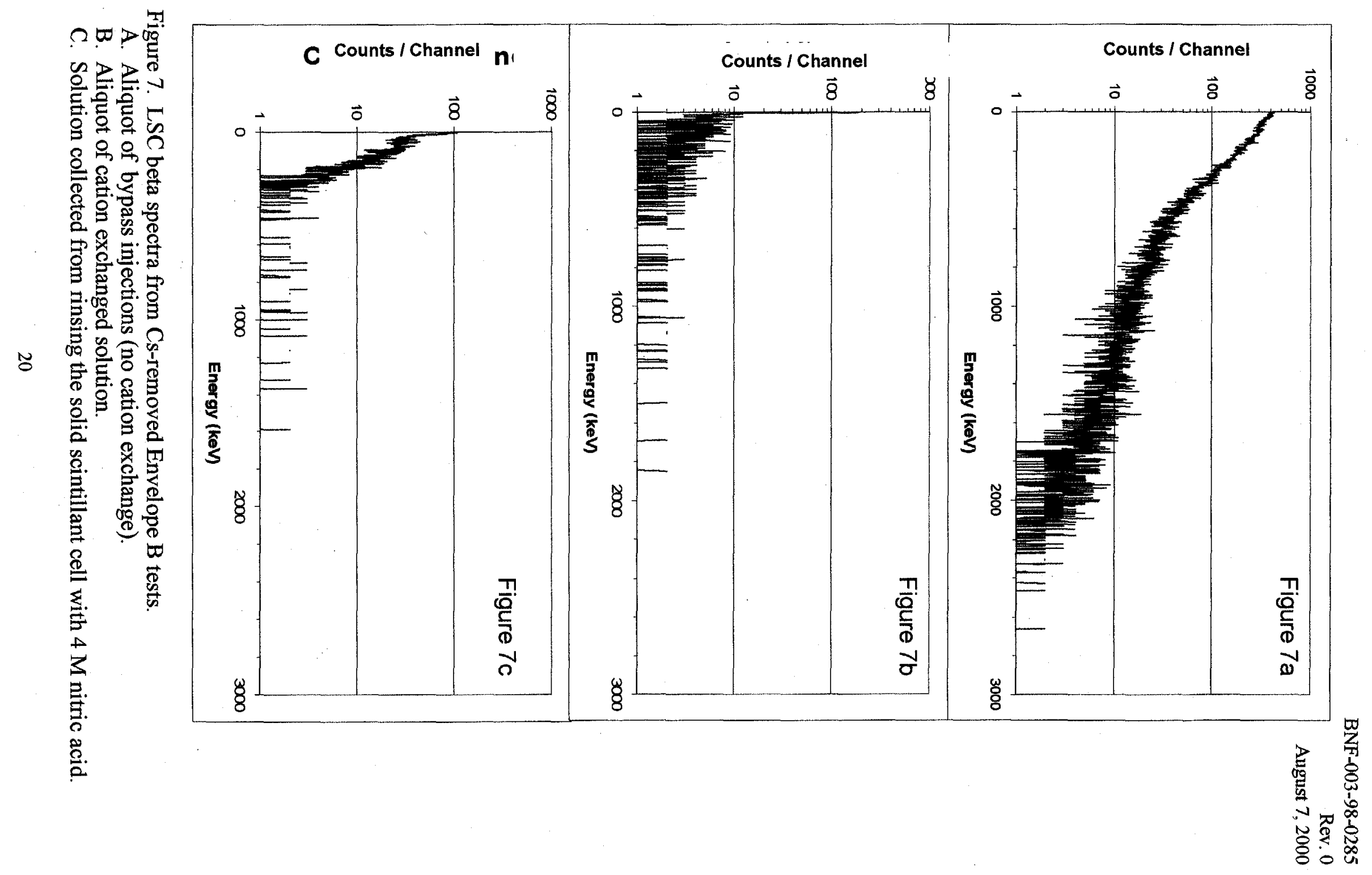




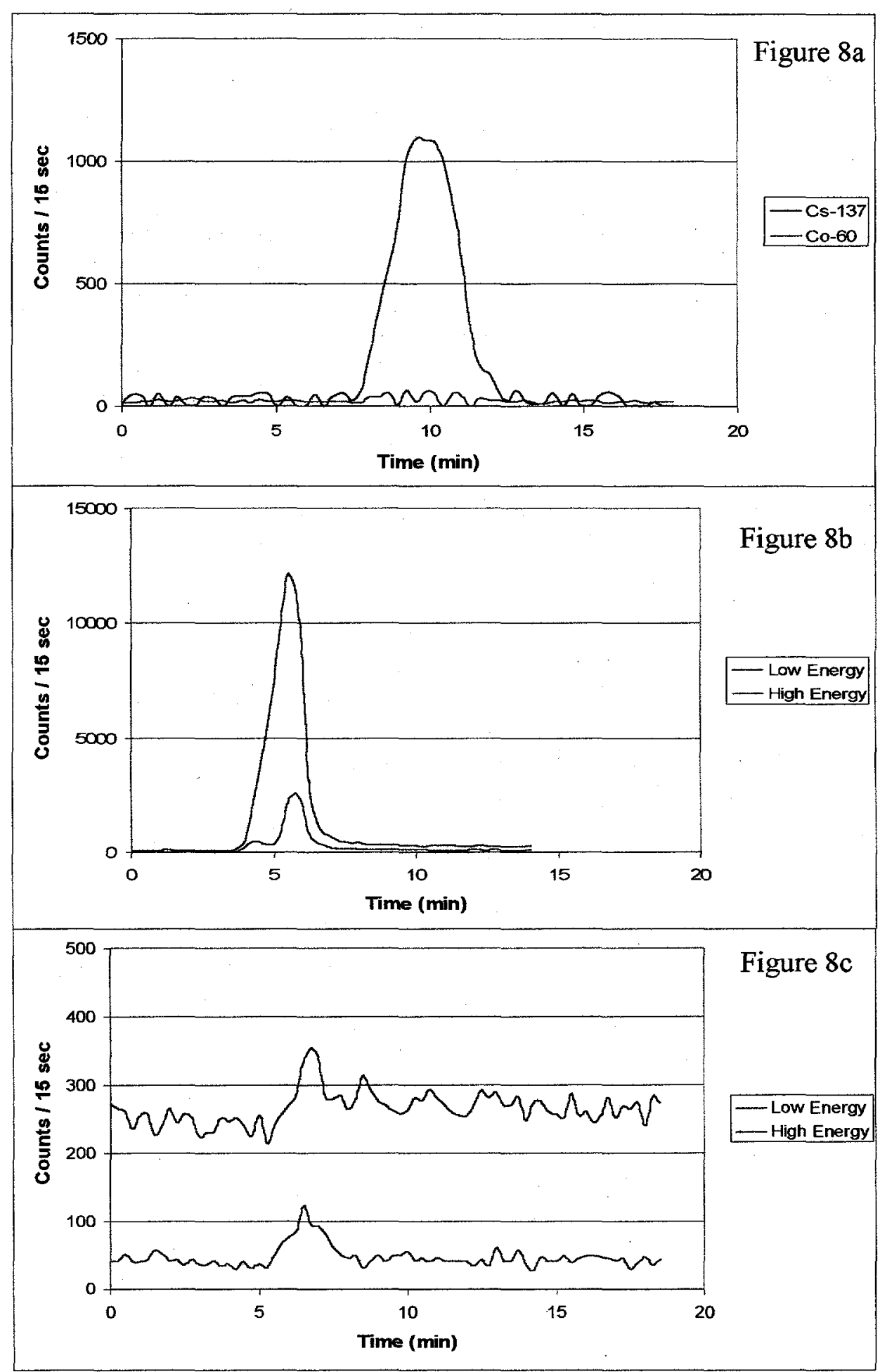

Figure 8. Hanford Cs-removed and Tc-removed Envelope B solution (AZ-102).

A. Gamma-ray data for an injection bypassing the cation exchange column.

B. Beta scintillation data for an injection without cation exchange.

C. Beta scintillation data for an injection with cation exchange.

Note the change in vertical scale between figures $a, b$ and $c$. The flow cell was not rinsed after the bypass injection; hence, the initial baseline is high. 


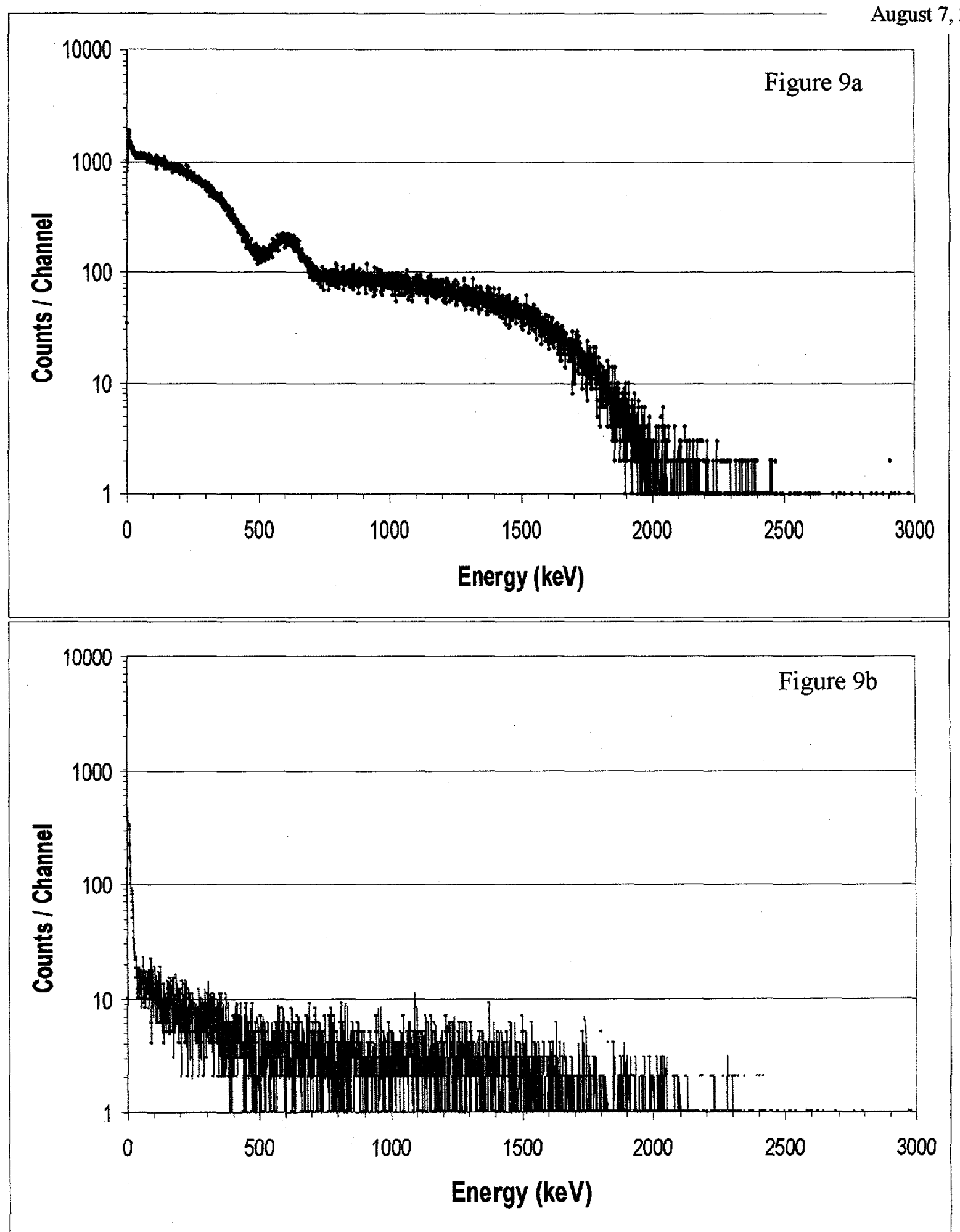

Figure 9. LSC beta spectra from Cs- and Tc-removed Envelope B tests.

A. Aliquot of feed (bypass) injections.

B. Aliquot of cation exchanged solution. 


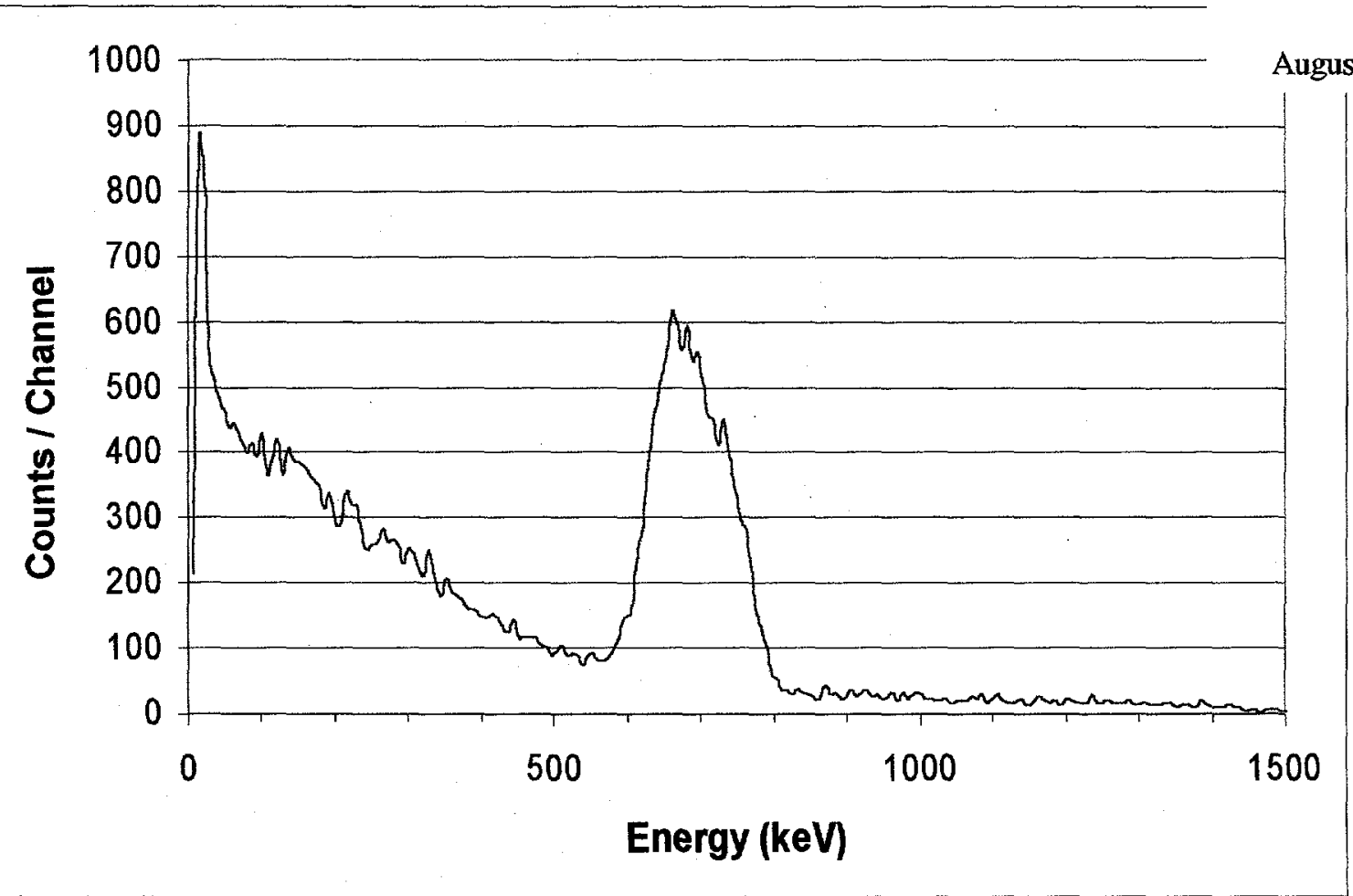

Figure 10a. Flow-through gamma-ray spectrum of Cs- and Tc-removed Envelope B feed to the cation exchange resin.

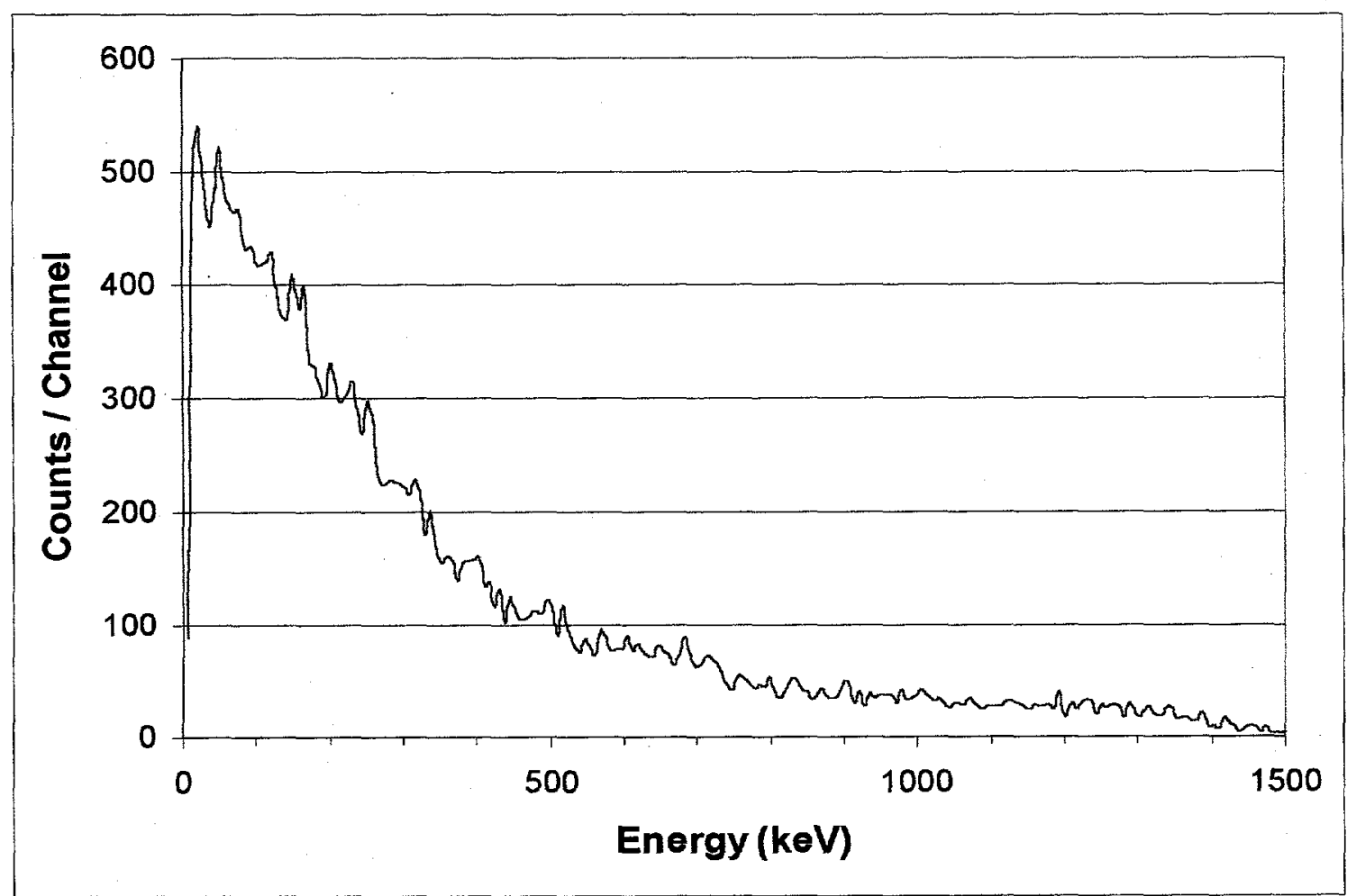

Figure 10b. Flow-through gamma-ray spectrum of Cs- and Tc-removed Envelope B product from the cation exchange resin. 